\title{
中樞興奮性藥物によろ催岷の實驗
}

\author{
小川和榮

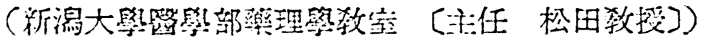 \\ （昭和二十七年四月十三日受付）
}

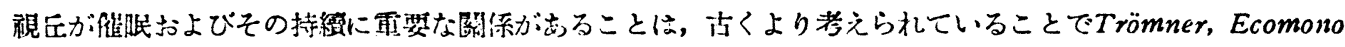

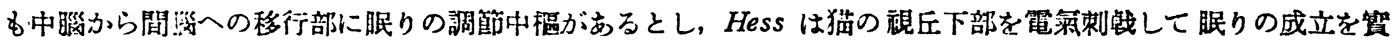

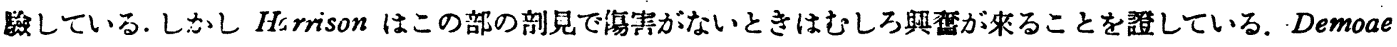

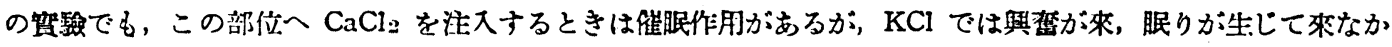

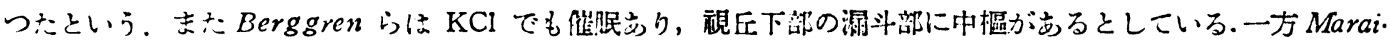

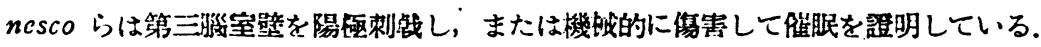

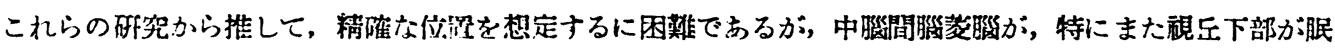

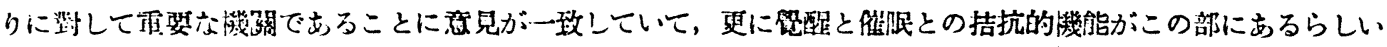
ことが想像できる。

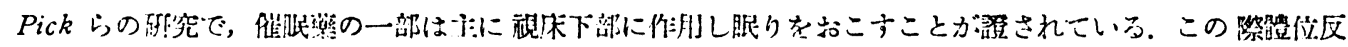

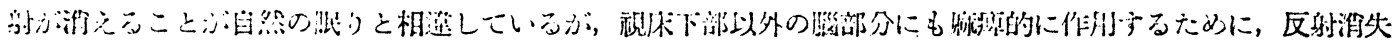

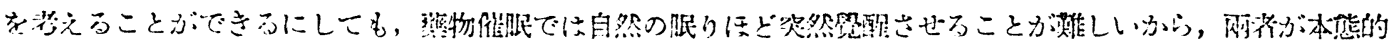

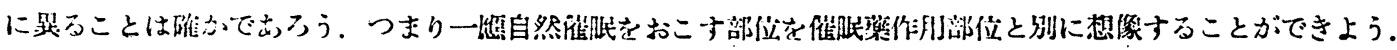

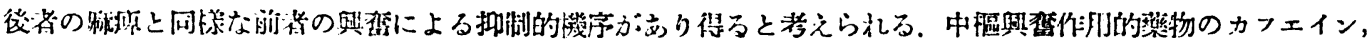

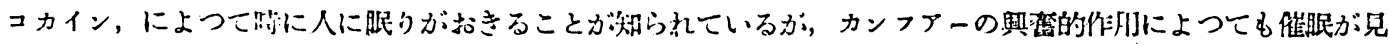

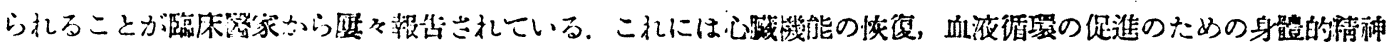

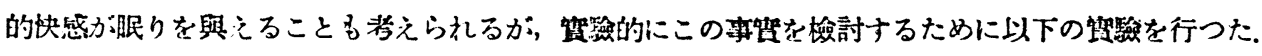

\section{融方 法}

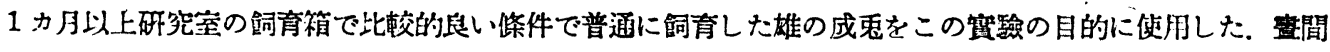

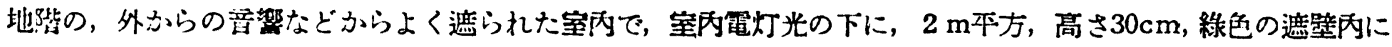

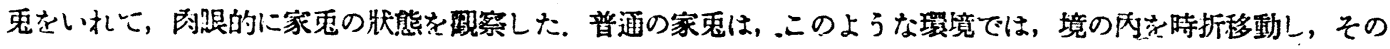

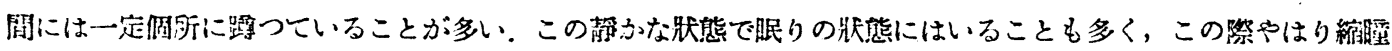

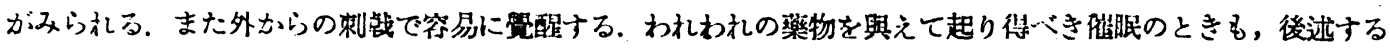

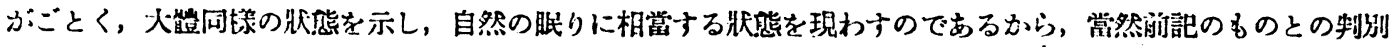

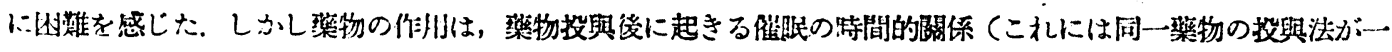
定ならば用昷の如何に拘らず作用の樶高はほぼ一致した時間に現われることを前提とする)その梁璂および目然 催眠との多少の相買によつてこれを制断する根㨜とした。

西

物

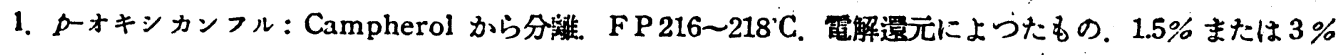

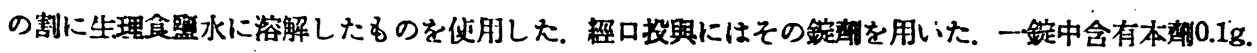

2. ビタカンフフー：Campherol から分離したもの，1.5\%の生理食盟水溶液.

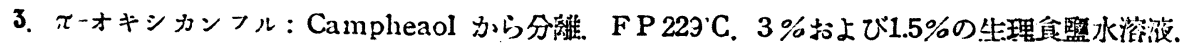

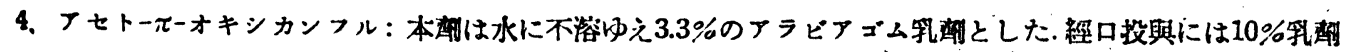


を打いた。

5. $\pi$ ーオキシおよびかーオキシカンフル：各同釷1.5\%宛，生理食曋水溶液.

6. $\pi$ ーオキシケトカンフル：2\%生理食洫水溶液.

7. $p$ ーニオキシカンフル: $1.5 \%$ 液.

8. ルト鹃䁅 (Ketoborneol): $1.5 \%$ 液.

9. 3ーブロムーp-オキシカンフル：FP 81 82'C，0.17\%液.

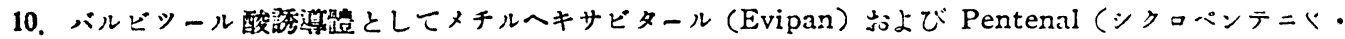
エチルーNメチルーパルピッール酸)を版いた，注射にはそれぞれ Na 盟を仗川した。

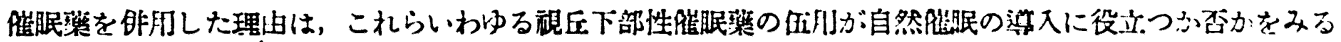
ためであつた.

\section{政成 綪}

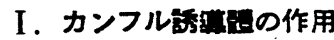

\section{A. p-オキシカンフル}

1. 皮下投 與

1）家鬼，雄（以下この記述を省く），2.5kg，1.5\%夜 $2.5 \mathrm{cc}$ を皮下に注射した．移動しつつむつたが $1^{\mathrm{m}}$ 後

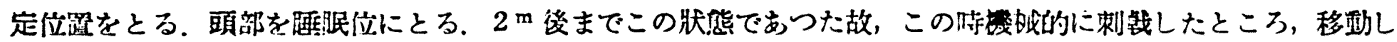

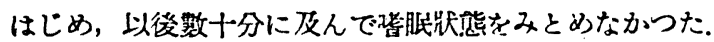

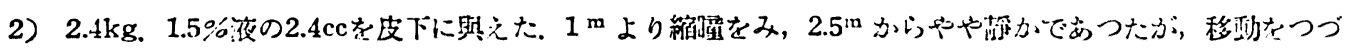
け郢眠なし。

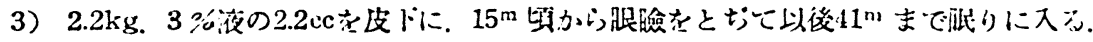

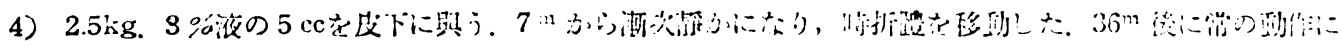
復したが, $1^{\mathrm{h}}$ 前後に再び約 $15^{\mathrm{m}}$ 間静かに罢つていた。

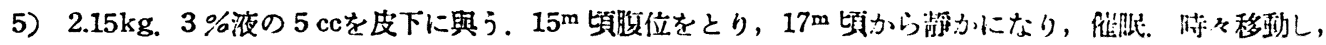
$1^{\text {h }}$ 頃加以 $40^{\text {in }}$ の間服り, 後正常の動作に移つた.

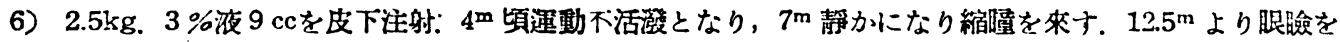

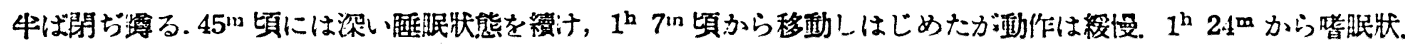
$1^{\text {h }} 30^{\mathrm{m}}$ から普通狀態.

7） $2.3 \mathrm{~kg} .3 \%$ 液 $9 \mathrm{cc}$ を皮下注射. $3^{\mathrm{m}}$ から眼臉を少し閉ぢ，11 $11^{\mathrm{m}}$ より $2^{\mathrm{b}}$ まで静止して睡眠．途中腹位に 移つた。

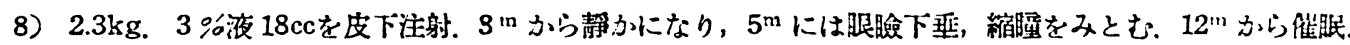

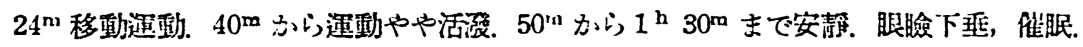

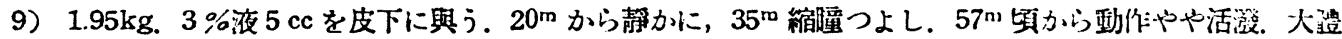
正常に復す.

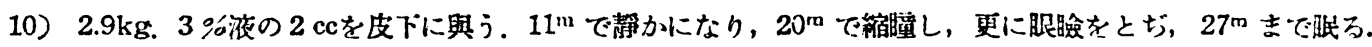

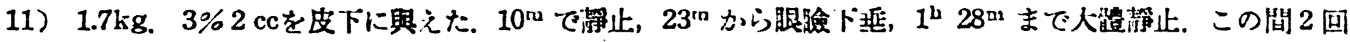
哣を移動した。

\section{2. 雪眼丙注射}

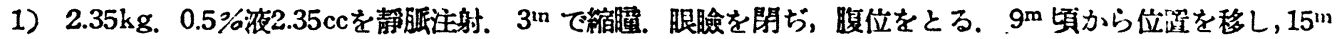
〜27辛, の間睡眠狀態.

2） $2.2 \mathrm{~kg} .1 .5 \%$ 液の $4.4 \mathrm{cc}$ 静腯注射した. $16^{\mathrm{m}}$ まで位圆一定となり，樎睡あり，眼瞼をとち催眠狀態に入 るす時队移動し，完全に眠ることがなかうた。

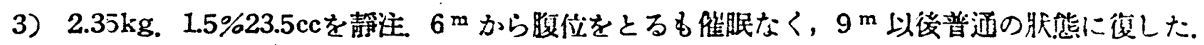

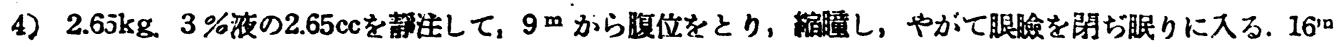


から正労の肤態.

\section{3. 经 口投 舆}

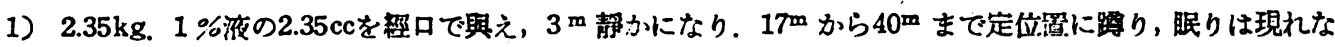
かつた.

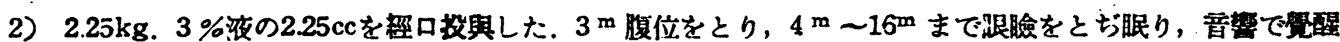

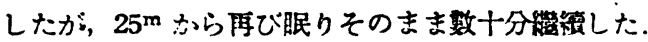

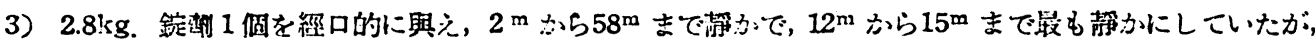
眠りはみられななつた。

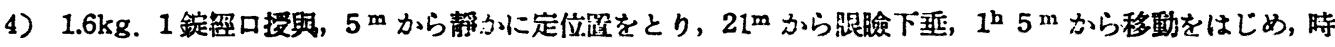
タ静かにしていることが多むつた。

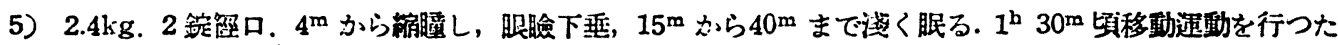

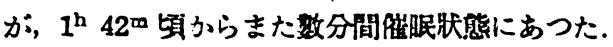

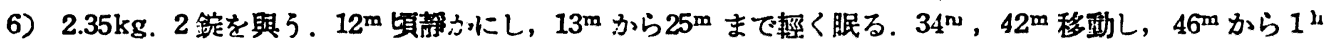
$35^{\mathrm{m}}$ まで静かに，时々眠りに入る。

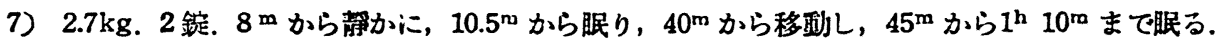

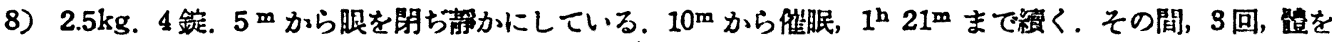
動かした。

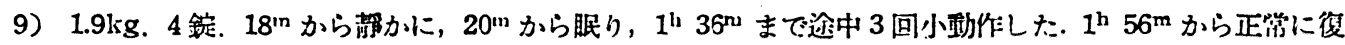
.Lた.

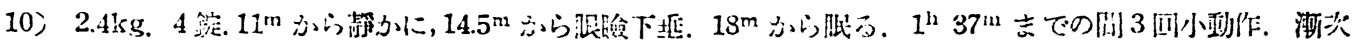
正梁に復した。

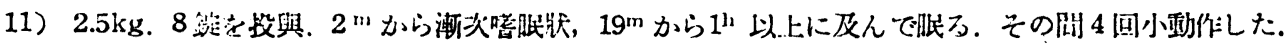

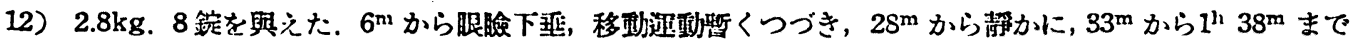

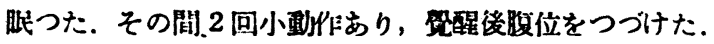

B. $\pi$-オキシカンフル

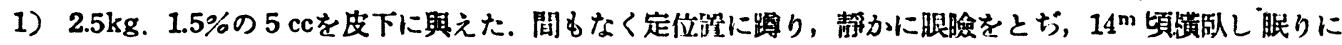

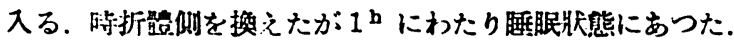

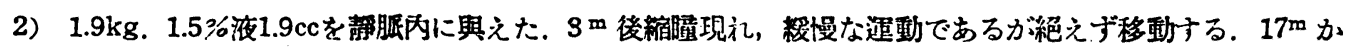
ら眼瞼下垂して㕷眠の狀を星したが芫全な眠りにスることはなかつた。

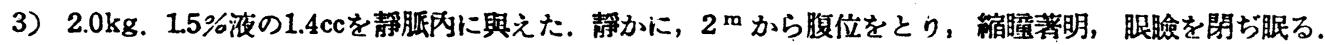
$15^{\mathrm{m}}$ から正常に復した。

4） $2.1 \mathrm{~kg} .1 .5 \%$ 液の $1.5 \mathrm{cc}$ 靜注. $11^{\mathrm{m}}$ から眠りがみられたが15 $\mathrm{m}$ から正常に復した。

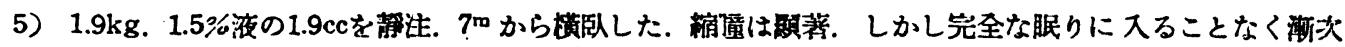
正常䡃作に復した。

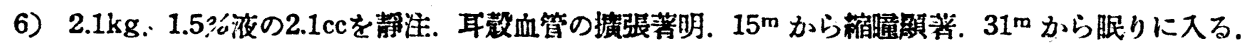

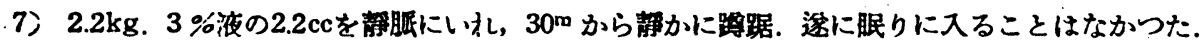

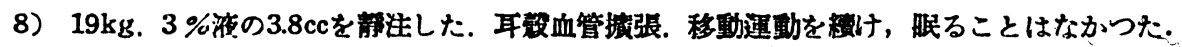

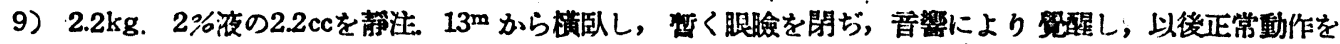
粮けた。

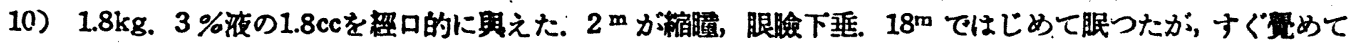
以後㱠ど正管.

11） $2.1 \mathrm{~kg} .9 \%$ 液2.1ccを程口投與，27n から $45^{\mathrm{m}}$ まで静かに，緶瞳をみ，以後正常に復し，眠りをみるこ とはなかつた。

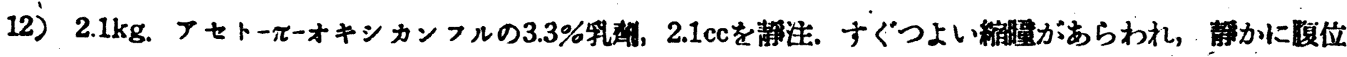




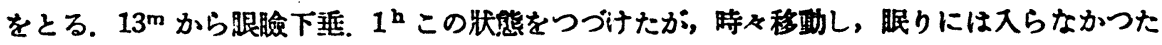

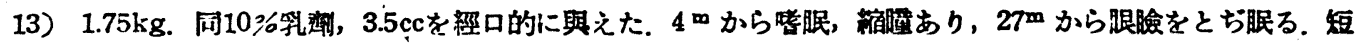
時間で笕めで，正常に復した。

C. $p$-及び $\pi$-オキシカンフル併用

1） $2.1 \mathrm{~kg} . \pi$ 、オキシカンフル及びか・オキシカンフル各1.5\%夜の1.05ccを同時に皮下に與えた． $38^{\mathrm{m}}$ に至り 静かになり，39m から眠りにいり暂く纕禎した。

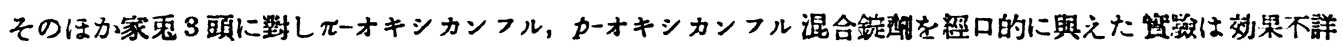
であつた.

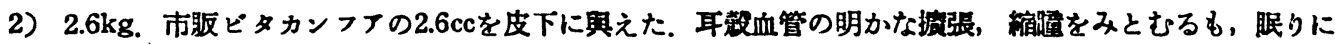
は入らなかつた。

D. $p$-二オキシカンフル

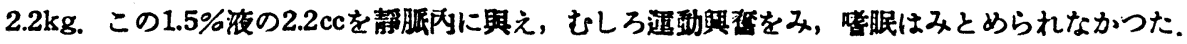

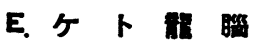

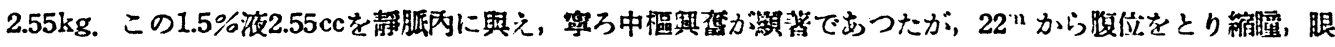

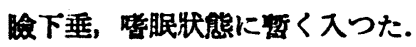

F. 3-プロムーp-オキシカンフル

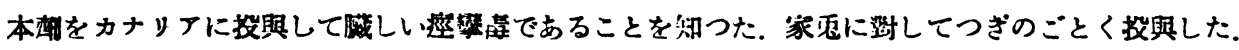

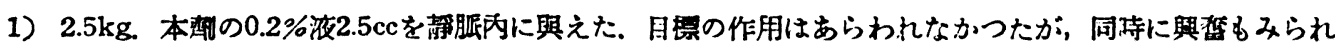
なかつた.

2） $2.8 \mathrm{~kg} ， 0.2 \%$ 液 $5.6 \mathrm{cc}$ 静脈内に與之，㱠ど異常さ貺察しなかつた。

\section{I. 催眼藥の作用}

A. メチルへキサピタール (Evipan 以下Eとかく)

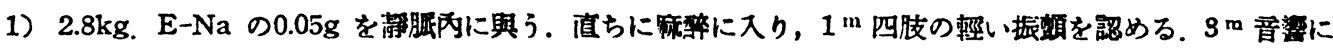

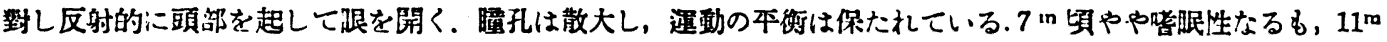
で第ど正常に復し盛んに移動運動を行う。

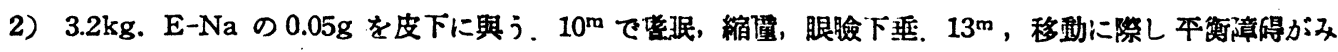

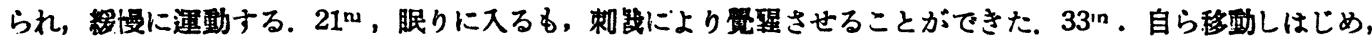
運動蹱碍をみとめず，殆上正常に復した。

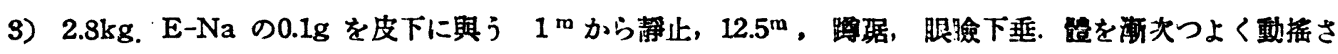

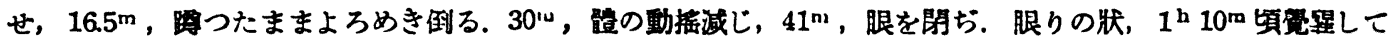
㱠ど正常に復す。

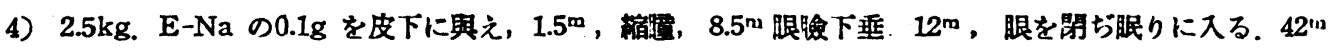

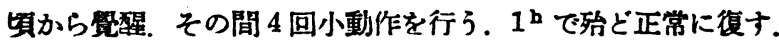

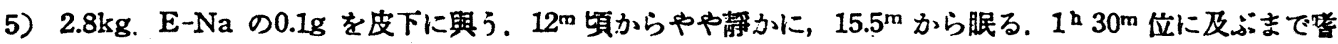
眠狀, 数回小動作を反貫す。

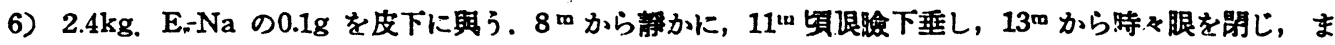
た時々移動し，この際運動障碍をみとめた。 $2^{\mathrm{h}}$ 餘に至るる逐に眠る゙ことはなかつた。

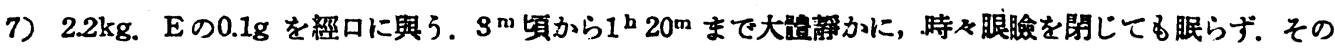
後移動しはじめ, $2^{\mathrm{h}} 30^{\mathrm{m}}$ から最す盛んに動く.

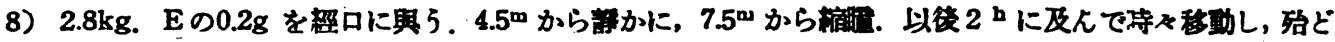
眠らぬ.

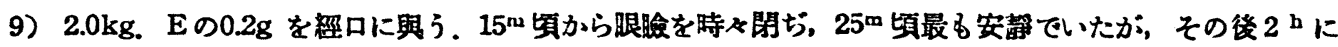
及んで眼ることはなかつた。 


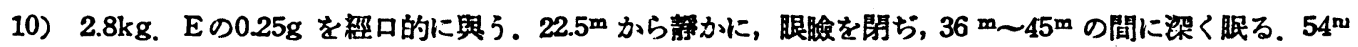

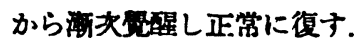

11） $1.6 \mathrm{~kg}$. Eの $0.3 \mathrm{~g}$ を䅅口的に與 5. $20^{\mathrm{m}}$ から静かに，40m 頁拙劣な運動を反復. $1^{\mathrm{h}} 10^{\mathrm{m}}$ から運動失調

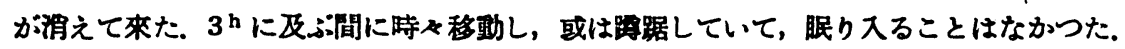

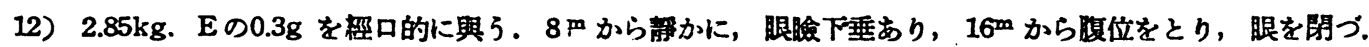

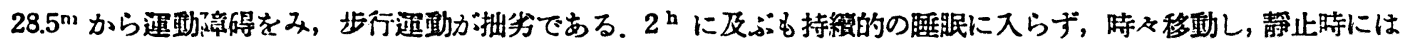
暨眠狀を示した。

13） $2.3 \mathrm{~kg}$. Eの $0.5 \mathrm{~g}$ を經口的に投與. $37^{\mathrm{m}}$ から眼瞼を閉ぢ，眠りをみるる，時ふ動作した. $1^{\mathrm{b}} 5^{\mathrm{m}}$ 頃暫く

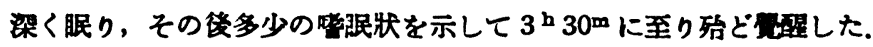

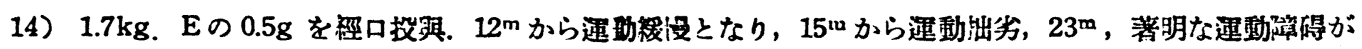

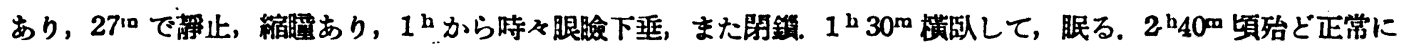
愎し，それまで持々眠りを催したが，睡りに入ることなく，遇動蹱䅞だけが䓔明であつた。

B. シクロペンテニル・エチル-N-メチルj・バルピツール酫（以下 P と畵く）

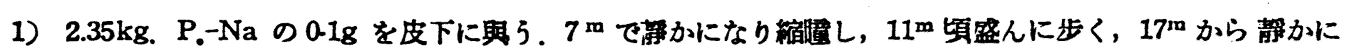

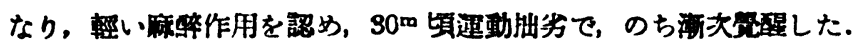

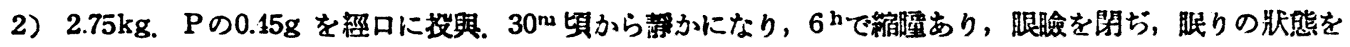
つづけ, $1^{\mathrm{b}} 50^{\mathrm{m}}$ で㱠ど躇した。

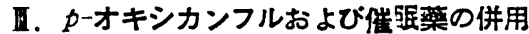

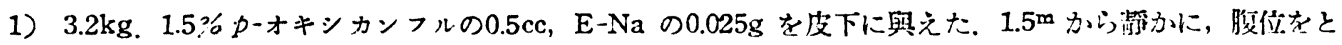

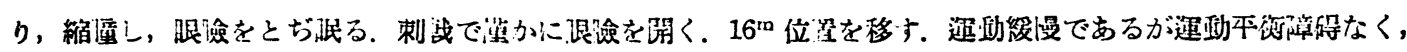
以後學腥した。

2） $2.4 \mathrm{~kg} .9 \%$ p-オキシカンフル液の $1.2 \mathrm{cc}, \mathrm{E}-\mathrm{Na} 0.024 \mathrm{~g}$ を皮下に與えた. $4.5^{\mathrm{m}}$ から搘眠狀, $5 \mathrm{~m}$ から服 睑を閉じた. $14^{\mathrm{m}}$ 刺钱で踶瑆し以後正常に得した。

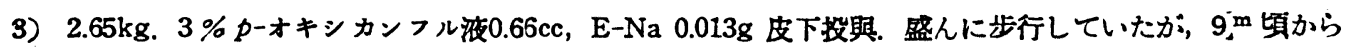

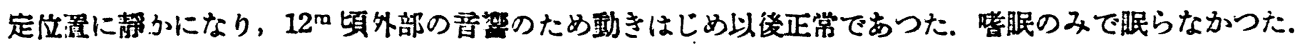

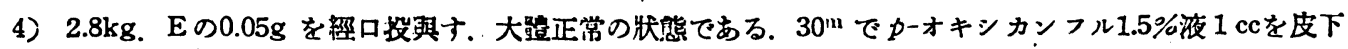

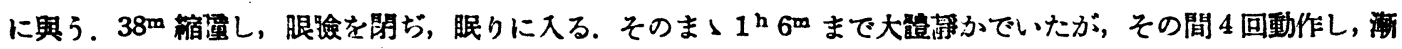
夷正常に復した.

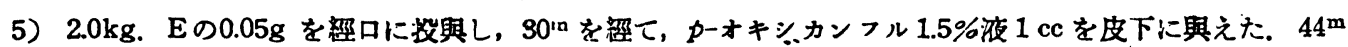

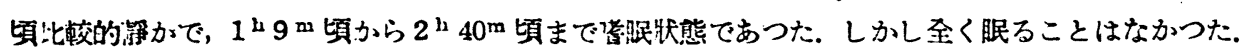

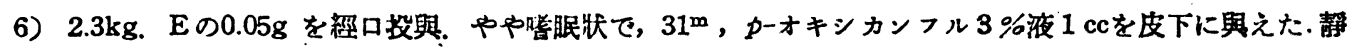
かにしていて， $1^{\mathrm{b}} 30^{\mathrm{m}}$ 頃庫子嘫眠狀を示したが全く眠ることはなかつた。

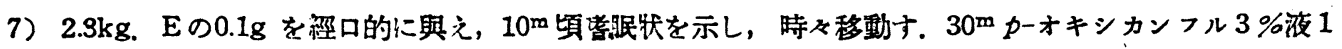

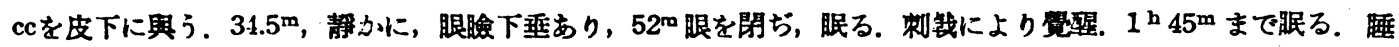

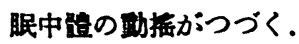

8） $1.6 \mathrm{~kg} . E$ Eの.1g を經口的に與う．20m 眼臉下垂あり，30m，p-オキシカンフル $3 \%$ 液の $1 \mathrm{cc}$ を皮下に

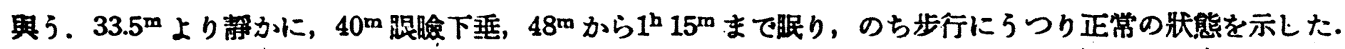

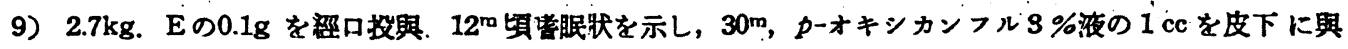

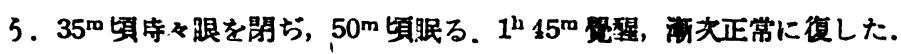

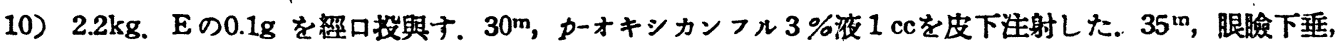

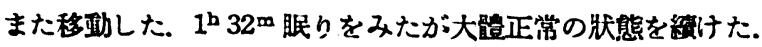

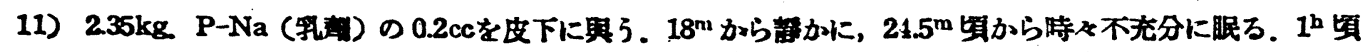




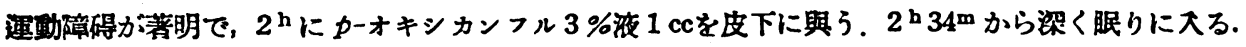

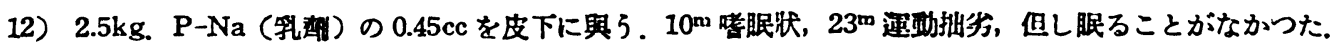

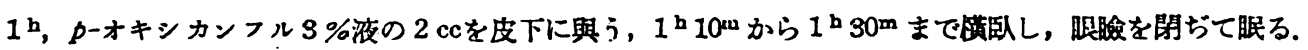

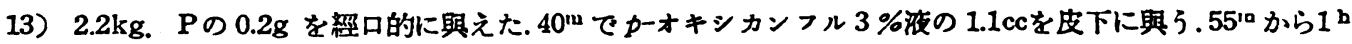
30

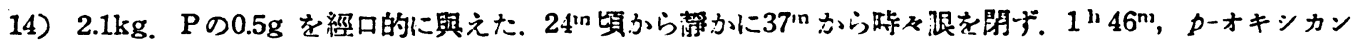

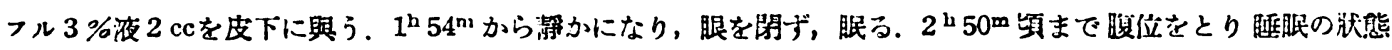
にあつたが，その間 2 回任ど能位を換えた。

\section{總括及ひ考察}

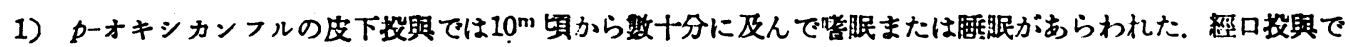

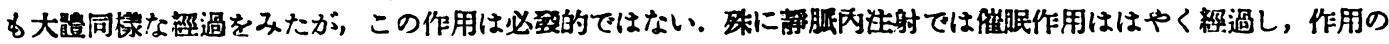

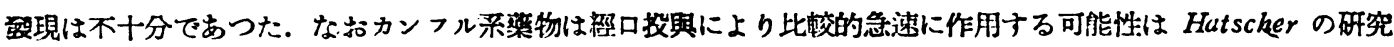
によつて明かである.

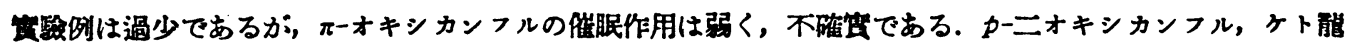

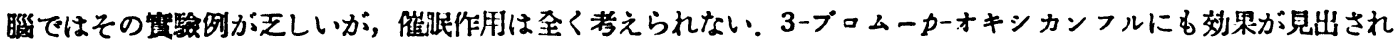
ない.

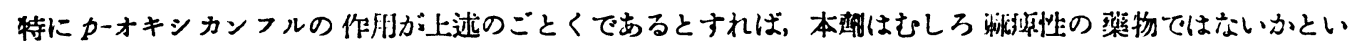

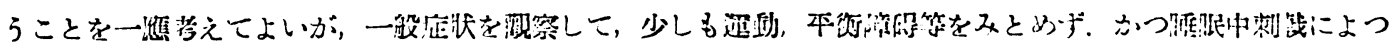

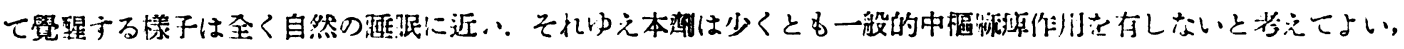

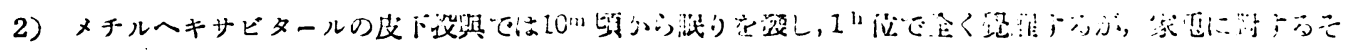

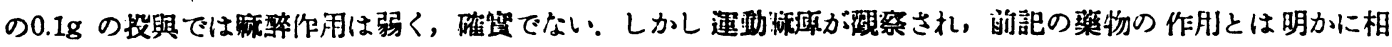
遠している。

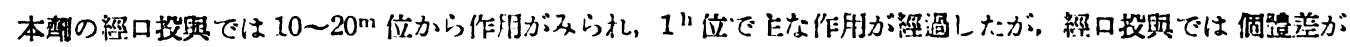

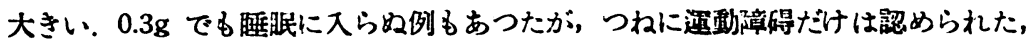

シクコバンテニルェチルーNメチルバルビッール酸も大體前者のごとく作打なることを知つた。

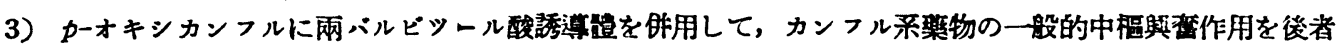

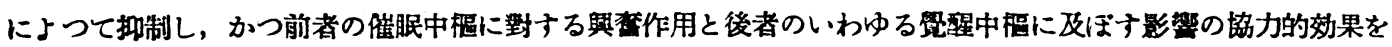
期待した筫驗を行つた。

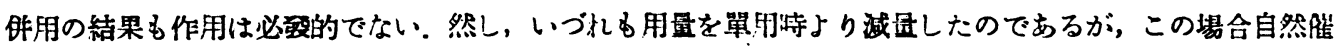

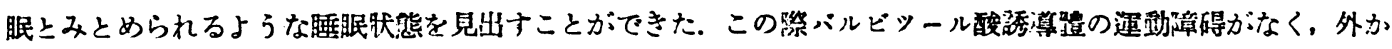
らの剌椷により祭醒させることが容易であつた。

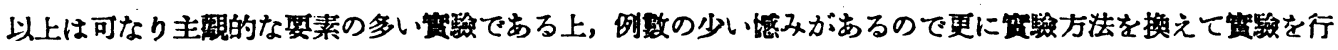
わなければならないと思つている。

別に人（健康な男子祭生）の十数名をして，pーオキシカンフル單用錠率，またはメチルヘキサビタール單用

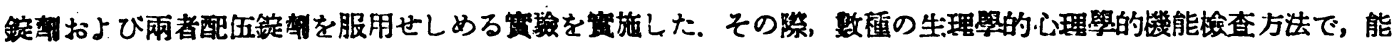
カ，機能の繁化を測定した。併用時にはメチルヘキサビタール單用時にみた機能低下を來さず，またかーオキシカ ンフル單用ではむしろ機能の可なりの上昇が々とめられた。

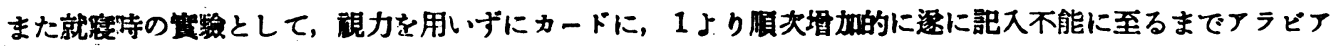

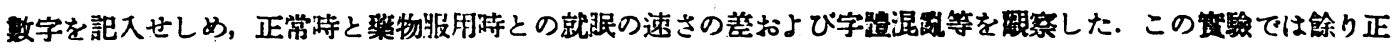
確な結果が得られず兩者に特別な差異がなかつた。

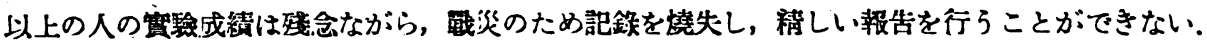


結 論

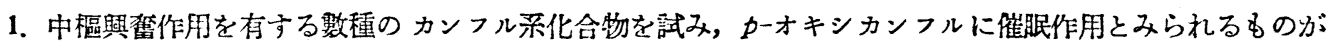
あつた.

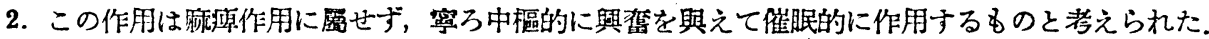

3.メチルヘキサビタール等を以上に研用してみて，自然的催眠作用において兩者は協力的に作用するすの と觀察された。

4.よつて中樞的には祭醒中樞とこれと捛抗する催眠中樞が目然の睡眠を調節している可能性がある.

本研究には，東大，田村罳造・石館守三兩教授の御援助大なりしことを惑謝する。

\section{引用㶳 目}

Berggen, S. et al. : Acta Psych. et Neur. 4, 1 (1929).

Demole, V. : Arch. exper. Path. u. Phaymakol, 120, 229 (1927).

Economo, C. V. :Über den Schlaf, Wien (1925).

Harrison, $F$. : J. Neurophys. 3, 156 (1940).

Hatscher, R. A. : J. Am. Med. Assoc. 55, 746 (1910).

Hess. W. R.: Die Methodik d. lokalis. Reizung und Ausschaltung subkortikaler Hirnabschnitte, Leipz ig (1932).

Marinesco, G. et al. : Zeitschr. ges. Neurol. u. Psychiat. 119, 277 (1929).

Pick, E. P. et a'. : Arch. exper. Path. u. Pharmakol. (1926-1930).

Troemner, E. : Problem des Sthlafs, Wiesbaden (1912). 
22. Fujishita, Harutoshi. Department of Pharmacology, Nagasaki University Schcol of Medicine, Nagasaki Studies of the excretion of santonin in rabbits (2). The relation. ship between the urinary excretion of santonin and liver function in rabbits (pp. 244-247) Tables 3

The influence of liver function on the urinary excretion of unchanged santonin was investigated in rabbits. The results obtained were as follows. After the liver was damaged by $\mathrm{CCl}_{4}$ the urinary excretion of santonin increased markedly over the control; it was decreased when the function of liver was stimulated by dehydrocholic acid or sodium thiosulphate. These results showed conversely the same relation that oxysantonin was excret. ed in the urine proportionally to the function of liver, and it was accord. ingly considered that' santonin would be changed to oxysantonin in liver.

Author

23. Fujitake, Nobuhide. Department of Pharmacology, Faculty of Medicine, Kyoto University, Kyoto Bioassay of anticonvulsants (pp. 248251) Tables 4

The anticonvulsive activities of such drugs as o-tolylglycerylether (Myanesin), guaiacol glycerylether, isotetradrin ammonium hydroxide, isotetrandrin ammonium chloride, isotrilobin and d-tubocurarine were comparatively examined by the head-drop dose of rabbits and mice and discussed on the superiority of the former method with rabbits to the latter.

\section{Yamada-Kyoto}

24. OGA W A, Kazue. Department of Pharmacology, Niigata Univer- sity School of Medicine, Niigata The hypnotic action of p-hydroxy-camphor (pp. 252-258)

It has been known that phydroxycamphor has a cardio-stimulating action. This drug used for the author's experiment has been prepared from campherol, being separated from the urine of a dog taking camphor. The drug seemed to have the action to get rabbits sleep naturally by this experiment. In the case in which it was used with a barbiturate such as evipal, the author found it to be certain that, as the former would have the antagonistic action in part against the latter, the paralytic action diminished and consequently sleep came on naturally in rabbits with the simultaneous application of both drugs. In the case in which these two drugs were administered together to the human body in the same way as bebore, it seemed certainly that they would act also antagonistically to each other at the site of action, so that their side actions diminished and they, therefore, caused sleep more naturally their synergistic action on the other hand. It may be said that sleep would come on with change of the state of two centers, sleeping and awaking; $p$ hydroxy-camphor excites the sleeping center, while barbiturates inhibit the awaking center, so that the human being would be taken in the natural sleep if he used these two drugs together.

Author

25. YamaMoto, Masaichi, FURUKAWA, Satoru, Matsuda, Katsuichi. Department of Pharmacology, Niigata University School of Medicine, Niigata $A$ experimental criticism about four-hours method as bioassay of digitalis (pp. 259-264) Tables 8 